\title{
THE IMPERATIVE OF COMMUNITY POLICING IN NIGERIA
}

\author{
Gabriel Izokpu OIKHALA \\ Department of Public Administration \\ Olabisi Onabanjo University, Ago-Iwoye, \\ Ogun State, Nigeria. \\ oikhala.gabriel@oouagoiwoye.edu.ng
}

\begin{abstract}
Across the world, the concern of governments to maintain public safety necessitated a reform for reorienting the police organisations to shift from conducting its functions through the incidence driven approach to community participation model. In Nigeria, the reactive model adopted appeared not effective in taming the internal insecurity across the country as crime upheaval is increasing daily. This paper examined the effects of community policing on police statutory functions in Nigeria. Data were collected from relevant textbooks, journals, newspapers and other official records. The data congregated were analysed through descriptive method. Espousing the broken window theory as theoretical framework, community policing is considered as a proactive crime and disorder reducing strategy as against the 'pursue and catch' reactive oriented. The paper found community policing as helpful to curbing internal security threats in Nigeria. It argued that the effectiveness of community policing is overturned by gamut of the police different operational agenda; inconsistency in policy; and resistance from some officers and rank and files. The paper recommended that the police statutory functions of curbing insecurity in Nigeria would remain a daydream without active community policing.
\end{abstract}

Keywords: Nigeria police, neighbourhood watch, intelligence sharing, problem solving, offence

\section{Introduction}

Keeping peace and maintaining safety of citizens and property cannot be over emphasised for the progress and survival of any sovereign nation. It can be viewed as a precondition for good governance leading to socio-economic growth, political advancement, national peace building, human capital development, human freedom and proper functioning of things in a country. There will be no doubt therefore, that absence of internal security breeds disorder, increase insecurity, distorts freedom, reduce human value, and impoverish the citizens. In this case, no country jokes over internal security. This was demonstrated when section 14 (2) (b) of the 1999 Constitution of the Federal Republic of Nigeria assigned the task of internal security as the primary function of government. Beyond this, section 214 of the Constitution went further to establish the Nigeria police force to lead the internal security architecture for the country (FGN, 1999). As a lead internal security agency in Nigeria, the police can be described as the first line of defence in Nigeria. They are to provide peace and assure the safety of everyone to attract development and good order. This implies that the "A to Z" functions of the Nigeria police force revolved round protective and enforcement duties. In other words, the police are responsible for keeping peace and stability; maintaining law and order; guaranteeing good order and proper functioning of public affairs. To fully understand what the police are expected to do, section 4 of the Police Act and Regulations (2020) defined in a broad term that the police are employed to prevent and detect crime; apprehend and persecute 
offenders; preserve law and order; protect life and property; enforce laws and regulations and perform such military duties within or outside Nigeria. In addition, the police are to solve crime and disorder related problems through police-community relations.

Abba (2014:3) observed the immensity of the Nigeria police functions and maintained that its statutory responsibilities require engagement in numerous activities that are concerned with crime control and prevention policies. These policies would be well framed and effectively implemented. Abba emphasised the need for a hearty intelligenceled gathering and visibility policing. These would involve vehicular and foot beat patrols; tactical point devices such as observation point, pin-down point, nipping point, hot-spot or vulnerable point, stop and search point among others. He concluded by saying that "police functions as at today have expanded and transcended the traditional surveillance function of walking the beat alone by police officers. Hence, a police officer on patrols is expected to engage in, and liaise with members of the public in problem solving” (Abba, 2014:3). The method of policing adopted earlier in Nigeria was the traditional incidence-driven model that does not encourage public participation. In all ramifications, the model has not been able to nip the gamut of awful crime and disorder in the bud. Many literatures supported this claim. For instance, Dickson (2007) documented that such manifestation is evidenced as no day passes without the national dailies in Nigeria carrying reports of one form of crime or another ranging from armed robbery, political motivated attack, gruesome murder, rape, bombing to burglary, stealing, corruption, fraud, ritual killings and so forth. Acknowledging the ineptness of the traditional police approach, Bello-Imam (2010:54) said that "members of the public see modern policing in Nigeria from the inception, as a profile of dissatisfaction that has lost public confidence.” Okolie \& Ezirim (2020) also saw the recent "\#EndSARS" protests in Nigeria as a reflection of public discontentment over the insufficient and inapt approach to policing in Nigeria.

But, the past and present governments with the police chiefs have made efforts to improve the police performance. The provision of section 14 (2) (c) of the 1999 Constitution that empowers citizens to participate in their government was being implemented. In this regards, police community relations committee (PCRC) was formed as a way of getting people from the local communities to involve in policing affairs through town-hall meeting. While the outcome is yet to achieve the expectation, Dawodu (2007) and Nwachukwu (2011) documented how the Federal Government and Police made further efforts towards ensuring a fruitful police system. According to Dawodu (2007:111), Dr Lee Patrick Brown of Houston in United States of America was contacted and he had series of discussions with President Olusegun Obasanjo in 2003 on how the idea of community policing would be useful for the police to curb the rising insecurity upheaval in Nigeria. In his opinion: "Community policing is about the police and the community jointly identifying problems, finding solutions to them, and raising combine resources to solve those problems. Everything about police has to start with the people at the neighbourhood level as each neighbourhood and community has different value system. There are many similarities than differences between policing in Nigeria and policing in United States of America and the Nigeria police officers are dedicated professionals who could do well if backed with adequate resources” (Dawodu, 2007:111).

Nwachukwu (2011:24) explained that the Inspector General of Police, Mustapha Adebayo Balogun led a five-policeman delegation to United State of America in 2003 to under-study how community policing can be applied in Nigeria. As he puts it, "the 
organisations and operations of the police departments in Houston, Atlanta, and Chicago were studied. The results showed effective community based policing." As they noted, field police officers in United States of America are deployed to work in their local communities. Besides, the police researchers saw that Houston with a population of two million has a total of nineteen thousand police personnel. This outcome spurred the Federal Government to approve in 2003 an annual recruitment of 40, 000 policemen to boost the working strength of 130,000 in Nigeria. As a follow-up, Chicago Community Policing Experts were invited to train some Police Officers on Community Policing duties in Nigeria. Thus, the Federal Government approved and launched the integration of Community Policing to the Nigeria Police system on 27th April, 2004.

This paper is designed to examine the effects of community policing on solving the unending internal security menaces in Nigeria. The paper is structured into seven parts. The first three parts dealt with introduction, theoretical, and conceptual issues while the last four sections focussed on the value of community policing; police-community participation in Nigeria; the community policing that is needed in Nigeria; and conclusion of the paper.

\section{Theoretical Framework}

In police studies, theoretical formulations are inter-connected and inter-related. At best, they are attempted by different intellectuals to make sense out of the extant multifaceted police crime administration. Hence, irrespective of perspicacity of any theory espoused, none can completely explain all the remote and immediate reasons for crime incidents and the best-fit approach of the police to deal with them. It is in line with the foregoing that this paper chooses the broken window theory as its theoretical basis. The theory was postulated by James Quinn Wilson and George Lee Kelling. It covers a wide range of issues, which are related to this paper. Among the main assumptions of the theory include the fact that unchecked minor visible signs of crime, civil disorder, and other trivial subversives or anti-social behaviours are direct causes of serious crime. It also perceived the unrepaired broken window as a sign that people are not paying close attention to safety issues. Hence, the repercussion of one unrepaired broken window of a building is an invitation for vandals to break more windows of the building. It is also an invitation for the vandals to make the vandalised building their hideout (Wilson \& Kelling, 1982). Before its popularisation as a theory, Scott Fraser and Phillip George Zimbardo conducted experiment to ascertain the broken window effects on police security administration. They brought two cars and removed their identification plate numbers. One of the cars was parked in Bronx along campus road of New York University. The second car was abandoned at Palo Alto in California, along the road to Stanford University campus (Zimbardo, 1969). As Zimbardo (1969:287) reported it: "What happened in New York was unbelievable. Within ten minutes, the 1959 Oldsmobile received its auto strippers from a father, mother, and eight year old son. The mother appeared to be a lookout. The son aided the father's search of the car, glove compartment, and the motor. He handed to his father the tools necessary to remove the battery and radiator."

In the contrary, the car parked at Palo Alto in California was intact for over a week. As Zimbardo (1969:290) described it, "the Palo Alto car not only emerged untouched; but, when it began to rain, one of the passers-by lowered the hood so that the motor would not 
get wet." As the car remained untouched, Zimbardo took a sledge-hammer with Mike Bond and Ebbe Ebbesen, who were his graduate students to the scene to smash the car. They were accosted by the neighbourhood residents and handed over to the police. It was concluded that Palo Alto is not vulnerable to crime and criminality because the neighbourhood residents are mindful of security. In the contrary, the Bronx community in New York would be vulnerable to insecurity because the inhabitants are not cautious of internal security. This view supported why the incident that occurred in United States of America on 11th September, 2001 failed to be averted. Like what happened in Bronx, the Homeland police was challenged and tactically shifted from its traditional-based pattern to community-oriented policing after the United States of America experienced attack on September 11, 2001(IACP, 2005).

In Nigeria, extant literature showed that the worrisome internal security challenges arising from the terrible cases of armed robbery, boko haram terrorist, Fulani herdsmen assailants, kidnapping for ransom and other banditries emerged from unbridled minor crimes such as political thugs, tribal soppiness, and petty stealing. For example, Toromade (2018) cited Atiku saying that boko haram terrorists in Nigeria started as political thugs. Also, historical narrative of the first and second celebrated Nigerian notorious executed robbers - Ishola Oyelusi (aka Dr Rob and Kill) and Lawrence Nomanyangbon Anini (alias The Law - Ovigbo) were allegedly started from stealing of pencil, fowl, and pickpocket (Adeola, 1987). As used in this paper, the thrust of broken window emphasised the spirit of police-community teamwork in policing as experienced in Palo Alto in California. It is believed that opportunity for boko haram terrorist group to come from Maiduguri in Borno State to effectively bomb Gboko or massacre people in Makurdi in Benue State will be very difficult. Besides, it will be uncomfortable for Fulani herdsmen from Yobe State to invade Ijebu-Ode in Ogun State and kill hundreds of people and escape without challenge. In addition, there will be a narrowed opportunity for criminals to invade schools and successfully kidnap hundreds of students in Chibok or elsewhere in Nigeria. In other words, crimes are not tolerated in neighbourhood where the police and people work in team spirit.

\section{Conceptual Issues}

Conceptualising police and its related terms has a lot of problems just like conceptualising other concepts in public administration. For a logical and better comprehension of this paper, some concepts like the Nigeria police force, neighbourhood watch, intelligence sharing, problem solving, offence, and community were explained.

\section{The Nigeria Police Force}

As noted in Oikhala (2019:42), in attempt to locate the meaning of the Nigeria police force, "people generically clarified the subject differently. This is because each country adopts the type and name of police system it thinks fit.” For instance, in Ghana, it is called Ghana police service and it is referred to as the Royal Canadian Mounted Police in Canada. In line with this paper, the definition of the Nigeria police force is elucidated in accordance with the law and intellectual perspective. As defined in section 214 (1) of the 1999 Constitution of the Federal Republic of Nigeria as amended: "there shall be a police for Nigeria, which shall be known as the Nigeria police force, and subject to the provisions of this section, no other police force shall be established for the Federation or any part 
thereof" (FGN, 1999). This is corroborated by Chapter P19, section 3 of the Police Act and Regulations (2020) when it said, "there shall be established for Nigeria a police to be known as the Nigeria police force” (The Nigeria Police Act and Regulations, 2020). The meaning of the Nigeria police force can also be located from its statutory functions. As documented in section 214 (2) (b) of the above quoted Nigerian Constitution, "the members of the Nigeria police shall have such powers and duties as maybe conferred upon them by law." In line with the constitution, section 4 of the Police Act and Regulations (2020) defined the general duties of the Nigeria police force as the prevention and detection of crime; apprehension of offenders; preservation of law and order; protection of life and property; and enforcement of laws and regulations; and performance of military duties within or outside Nigeria as may be required of them by law. In addition, the Nigeria police force is to collaborate with other security agencies to provide assistance to any person in distress, victims of road accidents, fire disaster, earthquakes, and flood. It is the of the Nigeria police force to clear obstruction and facilitate the free passage and movement on the highways, roads, and streets open to the public and to adopt community partnership in policing among others (The Police Act and Regulations, 2020).

The 2015 Administration of Criminal Justice Act (ACJA) affirmed the statutory functions of the Nigeria police force as prevention and detection of crimes. Its sections 5051 are relevant in this sense. As stated in section 50 of the ACJA, "prevention of offences and security for good behaviour shall be the purpose of the Nigeria police force." Furthermore, the ACJA provided that a police officer may intervene for the purpose of preventing crimes and shall to the best of his ability prevent the commission of an offence; prevent an injury attempted to be committed to any public property whether movable or immovable. Section 51 emphasised the covert crime information function of the Nigeria police force and how to manage the crime information for positive offence prevention outcomes. As further prescribed in section 51 of the ACJA, a police officer receiving information of a design to commit any offence "shall communicate the information to the officer to whom he is subordinate, and to any other officer whose duty is to prevent the offence, or take cognisance of the commission of the crime” (ACJA, 2015).

The angle of intellectual discourse is also looked at in attempt to locate the meaning of the Nigeria police force in this paper. As noted in Tobi \& Oikhala (2018:86), "establishment of the Nigeria police force was premised on the needs to promote internal security and socio-political order.” It was on this note, Shaw (2002:32) has rightly argued that "the ABC of the police stands for the protection of life and property; prevention of crime and disorder." In his contribution, Dawodu (2007:13) described the Nigeria police force as "one of the most visible and ubiquitous agents of Nigeria that presumably needs no formal introduction and definition beyond the obvious fact that it is the agent of the state, which is saddled with the responsibility for maintenance of law and order, detection and prevention of crime, protection of lives and property, and prosecution of offenders." Considered in a more formal way, Farm House Dialogue (1994:6) said it is "a civil force of the state." It is established by law, responsible for the maintenance of law and order through the protection of lives and detection of crime, enforcement of the laws of the land and the performance of other ancillary services (such as rescue operations) as determined by the state based on the peculiar needs, and the historical evolution of the state itself.

Drawing from the foregoing, it is obvious that the Nigeria police force is a critical agency of Nigerian state. It occupies first line of defence in Nigeria. To put it differently, 
the Nigeria police force is established by law to among others, keep peace and provide security; maintain law and order; promote good order and serenity to prevent any form of disorder against good governance and proper functioning of things in Nigeria. To this end, the Nigeria police force has to do everything that is necessary to protect life and property; prevent and detect crime. Therefore, the Nigeria police force are meant to conduct search, recover any stolen item, arrest, detain, investigate, arraign and prosecute offenders in court; preserve and enforce all laws; settle conflict through alternative dispute resolution; synergise with other security agencies to assist any person in distress or victim of accident and management of traffic issues just to mention only few of them.

The puzzling question however, is; with the suffocating insecurity upheaval in Nigeria at all levels, can the Nigeria police force be said to have reasonably performed the aforementioned duties? There is no gainsaying the fact that the manner in which minor crimes continues to develop into high profile or ferocious crimes daily suggested proper paradigm shift by the Nigeria police force to be more effective. As scholars documented, instances in which the efforts of the Nigeria police force appeared not good enough in enforcing law, keeping peace, and protecting life and property include the electoral violence of 1964-1965 and 1983; the religious confrontations in Kano, 1987 and 1991; Bauchi, 1991; Zango-Kataf in 1992 up to the outburst of dreadful Boko-Haram sect terrorist in 2009 and Fulani herdsmen banditry in 2014 (Toromade, 2018). This has ascended to insecurity of school children where kidnapping has turned into daily ritual. Just to mention only few, over 276 students of Government Girls Secondary School were kidnapped in Chibok on 24th April 2014; more than 110 students of Government Girls Science and Technical College were kidnapped in Dapchi on 19th February, 2018 while about 800 students of Government Science Boys Secondary School were allegedly kidnapped in Kankara on 11th December, 2020 among others. Most of these atrocities were all linked to the terrorist activities of boko haram that have grown from a mere political thug into terrorist group and kidnapper (Toromade, 2018; and Akinwotu, 2020). The big question will be where is the peace and security for establishing the Nigeria police force?

\section{Neighbourhood Watch}

The concept of neighbourhood watch means different things to different people. This makes it difficult for one best fit definition. For some thinkers, neighbourhood watch is the same as community police model. For instance, Sykes (1978:394) defined neighbourhood watch as community policing where the police and community members established "citizen advisory committees that would open up channels of communication between police officers and the community." In this sense, neighbourhood watch is used to mean the several ways in which community policing system is organised. There are some other thinkers in Nigeria who used the neighbourhood watch as same with vigilantism and community policing. In this case, the neighbourhood watch is being presented as territorial defence groups across Nigeria like the Amotekun of the Southwest and the Odua Peoples' Congress (OPC) of the Yoruba decent; the Bakassi of Ibo land; the Egbesu of Ijaw tribe; the Patari Soja in Tiv land; the Yan-banga of the Hausa extraction and many others (Chukwuma, 2003; Dickson, 2007; \& Yakubu, 2019). Drawing from the characteristics of some of these aforementioned outfits, they are considered as ethnic militias in this paper. Rather than a volunteer service, some of the outfits are not only recruited and equipped with lather weapon; they also received stipend from their local or 
state government. This makes them to be labelled as paramilitary. Hence, they can be used to fight a tribal or territorial war. The way and manner in which community policing operates does not contradict the operational framework of the neighbourhood watch. It is in the light of the above claim that Chukwuma (2003) described the neighbourhood watch as groups of people within a confinement of a village, city, urban, town, or rural locale who volunteered to guard the major entry or exit of community at night; patrol the streets while people are indoors and sleeping in order to protect their people from the threats of crime and criminals.

Unlike the ethnic militias or vigilantisms that use lather weapon, receive salaries, and kitted by most state governments, the neighbourhood watches captured in this paper do not enjoy such incentives. Instead of lather weapon, whistles are their major instruments to awaken the inhabitants when suspected unwholesome guests are perceived. Shaw (2000) argued against generalisation of vigilantism as neighbourhood watch as those groups labelled as National Vigilante Groups of Nigeria are groups of ex-servicemen. Apart from the nomination of certain categories of street members to carry out neighbourhood watch services such as the street surveys, night guards or patrols; the neighbourhood watch members are drawn from artisan, age grade, masquerade cult, hunter group, youth wing, trader association, scavenger unit, and palm-wine tipper group. The neighbourhood watch members also include the minister of hospitality or usher, boys' brigade, ambassador group, protocols or security committees in churches and mosques. Others are hisbah, sharia guards, daugeri, emanda, iwegua, body-guards, and ode, eso, ndichie-eze or palace guards for the traditional faith (Chukwuma, 2003). As said earlier, these volunteer groups are drawn from the various critical stakeholders of the community. If the police actively work in partnership with all these interests groups in conjunction with the community development association, the challenge of insecurity and the terrible crime threats in Nigeria ought to be abated.

\section{Intelligence Sharing}

Intelligence sharing, which is critical in active practice of community policing is marred with a problem of one-best-fit definition. This is probably due to the fact that there seems to be no fixed or unique way for the gathering and sharing of intelligence information in policing. Hence, some people choose to adopt a definition, which they considered would serve their interest and beneficial to the subject matter. As observed in the International Association of Chiefs of Police (IACP) (2005:3), "information is not intelligence. Intelligence is not what is collected. It is what is produced after the collected data are evaluated and analysed." Some thinkers and most police practitioners defined intelligence as exchanging security information between the police and the other security agencies. But, defining intelligence sharing in this manner would negate the aim of this paper. Aside from alienating the public from security business, it will also mean that the police have left out some critical elements in their information gathering and sharing. Hence, this lacuna limits the neighborhood contributions to police crime prevention and detection efforts. IACP (2005:11) noted that intelligence sharing as critical for decision making, planning, strategic aiming, and crime prevention. As it defined it, "intelligence sharing is a formal process of taking information and turning it into knowledge while ensuring that the information is collected, stored, and disseminated appropriately." Using intelligence from previous crimes in local and other jurisdictions, indicators can be created 
and shared among law enforcement agencies. "Comparing the indicators with local neighborhoods, analysts can anticipate crime trends and security agencies can take preventive measures to intervene." From the forgoing, intelligence sharing is a useful element in community policing. It allows the police and members of community to exchange information on issues relating to crimes or social disorder. Thus, it is clarified as information plus analysis and fair distribution of the outcome by the Nigeria police to necessary stakeholders to curb, control, or manage crime and criminality. It is a helpful process to limit the opportunity for crimes and genocides being committed by the boko haram terrorist group, kidnappers, Fulani herdsmen and other armed banditries in Nigeria.

\section{Problem-Solving Policing}

The concept of problem-solving policing defied a unanimous definition. But, attempt to locate the meaning of the subject-matter is focused on the objectives set for this paper. Thus, only related definitions were captured and discussed. Dawodu (2007:106) defined it as "a new era of policing in Nigeria, which was celebrated as a philosophy of paradigm shift to problem solving" He buttressed his opinion when he quoted IGP Ehindero saying, "I came on board with a vision and a mission that have been developed over the years; a vision about the sort of police force of my dream” (Dawodu, 2007:112). As noted in Goldstein (1990), the opportunity for kidnappers, terrorists, and other bandits to commit crimes are mired and neighborhood enjoys freedom from threats to lives and properties when the police are preoccupied with crime prevention management on means over ends. This implies that police should develop a method, which would watch out for those elements that promote crime related issues and prevent them from translating into actual crime through teamwork spirit between the police and the neighborhood.

Adopting this perspective simply means that the traditional culture of incidencedriven and preclusion of public participation in policing is being shifted to policecommunity teamwork for addressing crime related or socio-economic problems (Goldstein, 1977). As crime issues have shared relationship between socio-economic problems and socio-economic controls, the new approach is expected to engage the Nigeria police on interacting with the various government agencies assigned to provide these services to trash out the identified crime related issues. To say the least, most of the crimes committed in Nigeria are almost impossible if the spirit of problem-solving policing is active. The police are to engage the stakeholders in constant town-hall meetings to identify crime related issues. These include welfare issues such as unemployment, poverty, ethnoreligious intolerance, economic downturn, and policy summersault among others. According to Edo adage, "a hungry man is an angry man," this suggests that there may be little or nothing the police can do to prevent a man who is hungry from looking for food to eat. The situation in Nigeria got deteriorated that the country has been listed among the eight hungriest nations of the world (Soni, 2019). This is probably why the rate of crime and criminality are growing high on daily basis as most Nigerians are now pushed to the status of perpetual famish. In this regards, it is not unlikely that when the socio-economic continue to depress and most Nigerians are languishing, people would be tempted to pursue stomach infrastructure adventure anyhow. Arase (2016) also supported problem solving model as he enjoined police officers to embrace it and to engage in holding town hall meetings with members of the community they are serving to jointly identify, discuss, and solve crime related issues to prevent them from translating into actual crime. 


\section{Offence}

The concept of offence is interchangeably used as a crime. It is often used to refer to any act of wrongdoing, which makes a person doing such act to be sanctioned. Crime is a Latin word 'crimen,' meaning 'accusation' or 'fault.' When the words accusation and fault are married together, it would mean "a suspected offender." Adopting this clarification would digress a bit from the goal of this paper. This is because, in Nigeria situation; what is often recognised as a fault or wrongdoing in the North may be viewed as a mere moral act instead of wrongful act. Sections 387 and 388 of the Penal Code Act, 1960 defined adultery as a punishable wrongful act for a woman and a man in the North. In the contrary, the Criminal Code Act did not recognise such act as an offence in the Southern part of the same country. Some levels of inequalities are noticed in the award of punishment to offenders in the North and Southern parts of Nigeria. As contained in section 390 of the Criminal Code Act, 2004 that is used in the South, "any person who steals anything capable of being stolen is guilty of a felony, and is liable, if no other punishment is provided, to imprisonment for three years." In the case of the North, section 287 of the Penal Code Act, 1960 prescribed for a similar felonious offence as: "whoever commits theft shall be punished with imprisonment for a term which may extend to five years, or with fine, or with both.” So, attempt to locate the meaning of an offence in Nigeria has always faced with a challenge of one acceptable definition. Notwithstanding the inconsistencies of the law, this paper adopted the definition of crime provided especially by the Criminal Code Act (2004).

Sections 2, 3, 7, 11, and 22 of the Criminal Code Act (2004) defined offence and described kinds of offence, the parties to offence with liability and ignorance of law. According to section 2 of the aforesaid law, "an act or omission, which renders the person doing the act or making the omission liable to punishment under any Act or law, is called an offence." Section 11 reinforced the meaning of offence when it stated that "a person shall not be punished for doing an act or omitting to do an act unless the act or omission constituted an offence under the law in force when it occurred.” This suggests that except an act or omission is defined by law or any Act as an offence and punishment is prescribed, such an act is not actionable and no one can be arrested of doing such act or omitting to do such act. Section 3 named three kinds of offences as "felony, misdemeanour, and simple offence." It defined a felony as any offence, which is declared by law to be a felony, or is punishable, without proof of previous conviction, with death or with imprisonment for three years or more. A misdemeanour was defined by the Criminal Code as "any offence which is declared by law to be misdemeanour or is punishable by imprisonment for not less than six months but less than three years." As defined by the above law, "all offences, other than felonies and misdemeanours, are simple offences."

Going by the provision of section 7, "when an offence is committed, each of the following persons is deemed to have taken part in committing the offence and to be guilty of the offence; and may be charged with actually committing it.” This is to say:

(a) Every person who actually does the act or makes the omission, which constitutes the offence.

(b) Every person who does or omits to do any act for the purpose of enabling or aiding another person to commit the offence.

(c) Every person who aids another person in committing the offence. 
(d) Any person who conceals or procures any other person to commit the offence (Criminal Code Act, 2004).

Furthermore, the law prescribed that "in the fourth case, he may be charged either with himself committing the offence, concealing, or procuring its commission. A conviction of concealing or procuring the commission of an offence entails the same consequences in all respects as a conviction of committing the offence," (Criminal Code Act, 2004). In addition, the law held that any person who procures another to do or omit to do any of such act that if he had himself done the act or made the omission, the act or omission would have constituted an offence on his part, is guilty of an offence of the same kind, and is liable to the same punishment, as if he had himself done the act or made the omission; and he may be charged with himself for doing the act or making the omission (Criminal Code Act, 2004). Section 22 made clarification of claims of ignorance of law. As provided by law, ignorance of law does not afford any excuse for any act or omission, which would otherwise, constitutes an offence unless the knowledge of law by the offender is expressly declared to be an element of the offence (Criminal Code Act, 2004). This implies that the doctrine of "ignorantia legis non excusat" (ignorance of law is not an excuse) will hold in such offence.

From the above proceeding, an offence is used to mean crime. It is an illegal act that renders the offender liable for punishment as prescribed by law. With exception of the parties known to law, the police in their attempt to unravel the author of a crime are not expected to harass, interrogate, or apprehend any parent, relative, or guidance of ward who allegedly committed an offence. The influence of ethical imbalance and territorial value interests implicated the adoption of Criminal Code Act for Southern Nigeria and Penal Code Act for Northern Nigeria.

When there is no doubt that in a country that adopted two or more separate laws will experience unequal offence definition based on territorial value system. This is where the tenet of community policing favoured police deployment particularly of Inspectors and Rank and Files to their locality. Hence, it will be illogical for a rank and file police officer who is an indigene of Effik in Akwa Ibom State or Biu in Borno State to be deployed to protect people in Ago-Iwoye of Ogun State where such police officer is a complete stranger. The Ekti State Commissioner of Police, Tunde Mobayo supported this claim when he said that the police constables newly recruited into the Nigeria police force are to be posted to serve in the areas they come from and this will certainly reduce crime incidence and improve police performance (Oluwole, 2020).

\section{Community}

The term community has a common definitional challenge. In attempt to find its meaning, scholars chose to define it from their individual perspectives and the object of their interests. For instance, Igbo \& Anugwon (2001:20) defined community as a "population, which occupies a given area and shares similar system of rules and regulations controlling relationship with each other.” As Umeban (2008:75) puts it, "community means "a social group occupying a defined geographical area and whose members share common interest, historical background, cultural value, economic activities as well as basic social institutions." According to Dawodu (2007:106), Wilkins saw community as "the actual population, which occupies a given area bound to each other by a shared system of rules and regulations, which control their relationships with each other." This definition is 
similar to the one given by Igbo \& Anugwon (2001). Relying on the above definitions, the term community has to do with people living together; sharing common value system; belonging to common locality and lineage as well as pursuing common social-economic activities for their life fulfilments. It is in this stance, that Gordner (2014) traced the root of community policing to active collaboration between the police and the neighbourhood residents that share common invested interests and exercising team-spirit policing to keep peace through crime prevention, and rediscovery of foot patrol activities to guarantee their welfare. Without community involvement in policing system, the assurance of police operative for timely crime related information and their knowledge about criminal behaviour would always be nominal and a foretelling adventure. This simply suggests that ability of the Nigeria police to obtain timely intelligence information from the community residents depend on building robust teamwork spirit with the neighbourhood inhabitants. Importantly, it implies that the police must not isolate the people. The police must build trust and reassure keeping peace and providing safety for them. How would community dwellers that are being molested by some overzealous police officers willing to give genuine intelligence information to the police?

\section{The Imperative of Community Policing}

The philosophical breadth of community policing varies. In line with its divergence scales of coverage, some thinkers argued that community policing is not an answer to all the police problems. To fully understand the importance of community model in policing industry, the view of Gordner (2014:1) is cited. As he puts it: "Community policing is an answer to some problems facing modern policing. Very few agencies can claim that they have fully adopted the entire gamut of community policing. Community policing is more serious about reducing crime and disorder than the superficial brand of incidence-oriented. There is neither ironclad precise definition of community policing nor a set of specific activities that must always be included. A set of universally applicable principles and elements can be identified, but exactly how they are implemented should and must vary from place to place, because, jurisdictions and police agencies have differing needs and circumstances." The issue of geographical factor in conducting police business is emphasised from the above discourse. Apart from the fact that community policing is well underscored in Sir Robert Peel's nine principles of police of 1829 as noted in Gordner (2014), the police ability to discharge their duties are hinged on public support. Hence, the police are being referred to as the public and the public as the police. In this sense, community policing is presented as transcendent method for keeping public peace, maintaining good order, preventing and deterring crime and disorder through police-public joint efforts (Dawodu, 2007 \& Gordner, 2014). The application of community policing set principles is often determined by crime history, societal behaviour and value system. This is where situational crime prevention is favoured to reflect societal variance. From the above, community engagement, organisational transformation, problem solving, and organisational change among others are common tenets that would reflect the significance of community policing.

Supporting, Dawodu (2007:116) cited IGP Sunday Ehindero saying that "a paradigm shift to police-public partnership is a solution to police inability to solve the challenge of internal insecurity in Nigeria." This indicated that there will be a hard 
opportunity for criminals to commit crime and escape in any locality that practised active police-community engagement and collaboration in policing. For Onovo (2009), the Nigeria police force will continue to focus on building safer and stronger communities through the instrumentality of community policing. He noted that what matters to lawabiding citizens is ability of the police to respond to their security needs through policepublic partnership. As documented by Ibrahim (2017), the former Inspector General of Police, Solomon Arase expressed dismay that Nigeria has lacked a proper policy for internal security since her independence. Speaking as guest lecturer at a conference on policing the Nigerian federation organised by the National Institute for Policy and Strategic Studies (NIPSS), tagged "towards integrating community policing in Nigeria's security architecture,” IGP Arase identified community policing as viable model to fight against crime upheaval and maintain effective law and order in Nigeria. Buttressing his claim, he noted that in Nigeria, community policing was tested in twelve states and the outcome was positive.

From the discourse above, the activities involve in community policing are not just broad and vary from place to place; but, it has a wider span of elements loaded with array of activities. Parts of them are creating, maintaining, and strengthening synergies with avenues. These are meant to enhance police active participation in local sporting events including recreational and other relaxation or indoor affairs for building active policepublic partnership; activating robust synergies with other security agencies to guarantee effective intelligence gathering and sharing; holding of regular town-hall meetings. This is concerned with all stakeholders such as the community development association with its allied units of other civil society groups consisting of the transport workers unions; unions of artisan, medical, teacher, journalist, student, labour, ethno-religious bodies, community leaders, private enterprises, market and traders association among others. Apart from rebranding and redefining the mission and vision of the police to bring the police and members of the public together for teamwork policing in Nigeria, it helps to keep peace, maintain good order; increase police performance; reassure public safety and rebuild public trust on police. It was noted that despite the fact that community policing is being suffocated with large activities and expanses, it is not about creating or recruiting ethnic militias or parallel military defence for territorial or maintaining local uniform police parallel outfit such as the Amotekun allegedly formed and kitted by the South-west Governments. Community policing is not about advocacy for state police system. It is about the police partnering with neighbourhood residents to fight, prevent, and control crime together in order to keep peace and provide safety.

\section{The police and community participation in Nigeria}

Nwanguma (2012) documented that the official integration of community policing model in Nigeria police system was launched by the Federal Government on 27th April, 2004 in which Enugu State Police Command was used as a trial. The evaluation report of the trial showed that within the period, Enugu state had impressive reduction in quite numbers of cases. Some of these cases are affray, burglary, murder, stealing, rape, bank robbery, highway robbery, human-trafficking, communal clash or tribal crisis among others. It also showed tremendous improvement on the mundane relationship between the police and members of the community. As Nwanguma (2012:54) rightly puts it, "the 
outcome encouraged the police authority to include other eleven state police commands, which included Benue, Kano, Osun, Borno, Ogun, Abia, Anambra, Kaduna, Nasarawa, Edo, and Rivers that had history of high rates of crime." According to Nigeria Police Force Report (2011), integration of community policing has not only assisted to reduce the threats associated with the rising crime and disorder in all the pilot state police commands including reduction in the daily occurrences of boko haram terrorism, Fulani herdsmen banditry, and other serious crimes in Benue, Borno, and Kano states; it has helped to reduce the rampant incidences of kidnapping, bank robbery, and other heinous crimes cases in Osun, Edo, Ogun, and Rivers states. Beyond this, Nwanguma (2012:118) observed "significance reduction of reported cases of police extortions, and extra-judicial killings" (The Dawn Newspaper, 2011; \& Nwanguma, 2012). Emphasising the efficacy of the police-public teamwork, Alemika (2012) argued that the changing nature of communities and the shifting characteristics of crime like kidnapping for ransom, bank robbery, terrorism, corruption, ritual killings, and child-stealing among other violent crimes and public disorders are compelling reasons why the philosophy of community engagement in police system should not be ignored in Nigeria. This is also in tandem with what was observed in Bureau of Justice Assistance (1994) that innovative practice in which people are made to participate in policing within their localities will assist in curbing the eruption of violent-crimes and insecurity within many communities.

Dawodu, (2007:21) supported the above views when he said that "effective and efficient policing need the co-operation of the public within which the police operate." It is probably, in this sense that Abba as quoted in the Nigeria Police Force Order (2014:1) issued the celebrated "Force Order 464" to re-educate the Nigeria police personnel on the need to focus on patrol activity as one of the primary police functions for effective crime prevention; familiarising themselves with members of the public; rebuilding public confidence and trust in them; and fostering community co-operation with the police among others. IGP Solomon Arase as cited in Ibrahim (2017:7) said there is no debate about the efficacy of community policing model for keeping peace and providing safety; security management and control. As he said, "even among police personnel themselves, a research carried out in 14 states discovered that if community policing strategy is adopted, it could assist to eradicate most of the challenges attributed to the traditional reactive police culture." Yakubu (2019:1) equally documented that at the 11th National Development Submit of Traditional Rulers held in the Shehu Musa Yar'Adua Centre, Abuja held on 15th October, 2019, the Vice President Professor Yemi Osinbajo said that "a meticulous implementation of community policing would reduce internal insecurity and bring about peace and harmonious co-existence among Nigerians across the country.” This simply suggested that the integration of community policing into the Nigeria police force by the Federal Government on 27th April, 2004 has implementation challenge. Not contradicting the usefulness of community policing in Nigeria police system, Dandison (2007) held that police methods and technologies, such as motorised patrols and the use of rapid crime response techniques created greater rift between the police and members of the community. As he saw it, because the police officers no longer patrol their beats, they have difficulty to know the neighbourhood residents they are meant to serve and protect. This made the police to have less awareness and involvement in the problem of the community that they serve. 
Abba (2014:1) pitched tent from his understanding of the tenets of community policing to re-orient the police personnel and re-activate the Nigeria police patrol system. As he puts it, "Patrol is the backbone of crime prevention duties." Supporting, Arase (2016) maintained that modern policing and beat patrol strategies have expanded the roles of police beyond the traditional surveillance function of walking the beat alone. This indicates that members of the public would always expect the Nigeria police to provide an active and highly visible presence in the community to reassure the people of providing their safety needs and keeping peace in the community. But, if the fight against boko haram criminality and terrorism, Fulani herdsmen banditry, kidnapping, ritual and political killings in Nigeria among others is to be achieved through the integration of community based policing? Then, it should be expected that the Nigeria police and the Federal Government would not be in dilemma on how to reform the police to cope with the tensed insecurity across Nigeria? While the Nigeria police continue to receive thrash for its inability to keep peace and maintain security in Nigeria, the colossal killings and wanton destruction of lives and properties are increasing on daily basis. If the outcome of the community policing launched on 27th April, 2004 by the Federal Government was reported helpful in the twelve trial Police State Commands in Nigeria why was it abandoned?

Table 1: The Nigeria Police Operational Agenda for Crime Prevention Management in from 29th May 1999 to 31st January, 2021

\begin{tabular}{|c|c|c|c|}
\hline $\mathrm{S} / \mathrm{N}$ & Name & Tenure & Agenda \\
\hline 1 & IGP. M.A.K Smith & 1999-2002 & $\begin{array}{c}\text { 6-Points Agenda "Operation Redeeming the Lost } \\
\text { Glory” }\end{array}$ \\
\hline 2 & IGP. T.A. Balogun & $2002-2005$ & 8-Points Agenda “Operation Fire For Fire” \\
\hline 3 & IGP. S.G. Ehindero & 2005-2007 & $\begin{array}{l}\text { 7-Points Agenda "The Paradigm shifts in Police - } \\
\text { Operation to serve and to protect with Integrity. }\end{array}$ \\
\hline 4 & IGP. M.M. Okiro & 2007-2009 & 9-Ways Test Agenda \\
\hline 5 & IGP. H. A. Ringim & $2010-2012$ & $\begin{array}{c}\text { 5-Point Agenda "Operation taking the Force to } \\
\text { Greater Heights” }\end{array}$ \\
\hline 6 & IGP. H. A. Ringim & $2010-2012$ & $\begin{array}{c}\text { 5-Point Agenda “Operation taking the Force to } \\
\text { Greater Heights” }\end{array}$ \\
\hline 7 & IGP.M.D. Abubakar & 2012-2014 & 6-Points Agenda “Operation Restore Hope” \\
\hline 8 & IGP. S. Abba & 2014-2015 & $\begin{array}{c}\text { 8-Points Agenda "Operation leading the Force to its } \\
\text { Prime” }\end{array}$ \\
\hline 9 & IGP. S.E. Arase & $2015-2016$ & $\begin{array}{c}\text { 8-Strategic Policing Plans “A Wake-up Call to the } \\
\text { Nigeria Police Force” }\end{array}$ \\
\hline 10 & IGP. I.K. Idris & $2016-2019$ & $\begin{array}{l}\text { 10-Points Agenda “Police Welfare/War against } \\
\text { Crime. }\end{array}$ \\
\hline 11 & IGP.A.M. Adamu & $2019-2021$ & Welfare Agenda "Operation Restore the Lost Glory" \\
\hline
\end{tabular}




\begin{tabular}{|c|c|c|c|}
\hline 12 & AG. IGP U.B. Alkali & Incumbent & $\begin{array}{c}\text { 12-Points Agenda "Operation Restore Public } \\
\text { Confidence in the Force" }\end{array}$ \\
\hline
\end{tabular}

Source: The Nigeria Police Force, 'B' Department Operations, 2021

The data presented in table 1 above, showed a significant disconnect with active community policing in Nigeria police system. It revealed desperate efforts of each Inspector General of Police launching different agenda to keep peace, provide safety, fight crime, enforce law and maintain order. The data portrayed some challenges inability to institutionalise a common operational framework for crime control and management in the Nigeria police force. The data from the table showed most of the agenda overlapped and it indicated a sign of mere repetition. Hence, Ikuteyijo and Rotimi (2010:24) describe it as "rhetoric ritual. One lesson that we have learnt is that when government talks about police reform or when every new Inspector General of Police waves the banner of reform, they do so merely as an attention grabbling gesture and as an opportunity to spend more money and award contracts and none of the reforms has positively improved the insecurity in Nigeria." Apart from the challenge of professionalism, the data from the table showed the inability of the Federal Government to pay regular salaries to serving police officers; provide kit and accoutrement to the police. If at this moment of the 21st century, an Inspector General is made to pursue "regular payment of police salaries and supply a two pair uniform and shoe in a year," it indicted the Federal Government for not given adequate attention to keeping peace and providing safety for Nigerians. Would it be possible for police to keep peace and provide Nigerian safety needs with empty stomach? Or would the police go to work naked? If it is difficult for Federal to pay police salaries and provide their mere working uniforms, how is possible for the Federal Government to provide the required modern operational gadgets to keep peace and provide good order for Nigeria? In all, the data presented in table 1 captured the need to activate community policing system where the police would spend less public fund as the police and members of the community would work in collaboration.

Yakubu (2019) documented how the Vice President, Professor Yemi Osinbajo reaffirmed the commitment of the Federal Government to fully implement community policing model when he pleaded for supports of the traditional rulers across the country. As Ordu \& Nnam (2017:85) put it "traditional rulers have roles in making the operation of community policing successful in Nigeria." As noted, traditional rulers have organised structures in which they interact with their subjects on daily basis. Since, the cabinet members of the traditional rulers consist of all the various community leaders who are drawn from all the clans, villages, districts, towns, and all the existing unions or associations, and interest groups such as the age grade, scavenger, hunter group, dance group, women group, opinion leaders, community development association, other occupational groups, and other groups within their area of jurisdictions, it will be difficult to breed or hide any criminal or cover crime. There is no gainsaying the fact that most of the criminals are well known in their various communities and sometimes, some policemen knew them. Thus, the criminals are not spirits and they are not living in the spirit world. Therefore, the bulk of intelligence information needed by the police to provide security and keep peace in their areas of responsibility will be gathered and shared within the areas. This is in line with Yoruba adage that "Kokoro to nje efo, ara efo lowa," meaning the 
insect that eats vegetable resides inside the vegetable.” As a process, community policing bonds police with residents of the neighbourhood. It gets the community directly involved in solving both criminal and civil disorder. When traditional rulers and their subjects are well involved in policing, there would be little or no opportunities for crime and criminality within the localities.

The manner in which the Nigeria police have embarked on community policing recruitment of interested and qualified applicants with effect from 2020 is another issue of discourse. The prescribed conditions for recruitment of the new community policing constables required interested applicant to be between the age of 17 and 25 years. Also, every applicant is expected to possess National Identity Number (NIN); a minimum of five O'Level credits in not more than two sittings including English Language and Mathematics. However, an applicant with knock knees, bow legs, or bent knees is not qualified. In addition, a pregnant female applicant is not eligible (The Nigeria Police Force, Department of Training, 2020/2021). From public commentary, the new community policing constables are still being trained by police instructors or facilitators with old traditional policing orientations. They are being deployed to their place of origins but are posted to field duties under the control of their superior in ranks. From the understanding of this paper, these police constables are being trained and deployed to field work under the tutelage of their superior in ranks having orientation of the traditional policing system. Hence, the Nigeria police force is yet to integrate the kind of community policing that would enhance its performance. One notable value of this policy at the moment is the employment opportunity for the thousands of unemployed Nigerian youths who were looking for job over a long time. It reduces the acute shortage of manpower in Nigeria police.

\section{The community policing that is needed in Nigeria}

Arase as documented in Ibrahim (2017) expressed optimism that integrating community policing would assist in the fight against crime and maintenance of law and order in Nigeria. Buttressing his view, Dr Solomon Arase who is a former Inspector General of Police argued that community policing is historically the rock upon which policing and internal security management can be improved in Nigeria. To him, the local communities have practised community policing effectively long before the colonial period. But, since Nigeria got independence; the country is yet to adopt a workable national policy on internal security. On how community policing would work well for Nigeria, the former police chief advocated for effective police-public partnership to fight and prevent crime. This suggests that community policing policy in Nigeria should have distinct principles and pathways to strengthening public trust and building partnership between police and the citizens. It is in this sense, that the needed national policy on internal security will define corridors for the achievement of community policing vision. When late President Umar Musa Yar’Adua unfolded seven points’ agenda on 29th May, 2007 for effective governance, which consisted of tackling internal security conundrum; Nigerians expected the sitting Inspector General of Police, Mr Mike Okiro to handle the internal security aspect of the federal government agenda. As expected, the Police Chief presented some creative ideas to transform the Nigeria police force through introduction of "A Nine Way Test Agenda.” It focuses on crime prevention through community policing; re- 
training and development of personnel for human capacity building; improvement on police-public relations; intelligence-led policing using neighbourhood and inter-agency collaboration to wage war against corruption and crime among others among others (Okiro, 2007). As Okiro noted, community policing is rooted to a systematic connection with the police and the people they serve. Therefore, the police responsibilities are not limited to law enforcement but to tackle a wide range of community problems. To realise such obligations, the police must be part of, and not apart from the community they are meant to serve (Okiro, 2007; \& The Dawn Newspaper, 2011). Ikuteyijo (2009:286) said community policing entails community partnership in creating a safe and secure environment for all. It is a kind of policing whereby the people take active part in their own affairs. With community policing, "the police are not seen as a stranger whose presence stands for danger and imminent hazard but as partners in development."

Drawing from the above point of views, this paper is concerned with the way and manner in which community policing would improve service delivery of the Nigeria police force; effectively reduce crime and criminality in Nigeria. It is about how to improve the unfriendly police-community relationship and how to integrate workable policecommunity engagement in policing. The paper is bordered on how to profitably activate police-public relations to develop neighbourhood watch approach; and heighten problem solving process to collaborate in sharing police functions with neighbourhood residents in attempt to keep the peace and provide the needed safety for all. This paper is about having a police system that is reliable, dependable and which can be on the same page with members of the public. This is the basis of relevance of the broken window theory.

In fact, the strategy of the kind of community policing that is appropriate and would be useful in Nigerian factor must be aligned with or rooted to the halls of the broken window theory. If the spirit of the police-neighbourhood teamwork is supported and well implemented in which the traditional rulers with their subjects are actively involved, there will be a limited opportunity for criminal to plan and execute crime. Also, it will be difficult for criminal to successfully maintain a hideout within the neighbourhood. All these views supported Okeshola \& Mudiare (2013:134) who argued that "the police must share power with the residents of a community while key decisions should be made along with the neighbourhood dwellers.” In a nutshell, the paper has identified with the elements like change management, community partnership, community engagement, organisational transformation, and self-help, which are expected to reflect in application of community policing in Nigerian situation.

\section{Change Management}

The change management canvassed in this paper is that the Inspector General of Police should re-design soft patterns of new orientation and flexible managerial innovation for the neighbourhood residents to be actively involved in policing their areas. With this, members of the community will see themselves as parts of policing process in their areas in which they share invested interests. Hence, it was argued that a wise man does not allow doom to befall his ancestral home for he has no place to run to (Arase, 2016). If the field police officers are re-educated to courteously work with the community members rather than dictating what they should do and police actions are made to reflect public interest, there will be a limited opportunity for crime and criminal to be tolerated in Nigerian communities. This is in tandem with Abba (2014:7) who said that "beat patrol and tactical 
operation points are universally acknowledged as the most effective tools of crime prevention. Other than detecting crime and arresting offenders on the run, the strategy affords the police opportunity of establishing close contact with members of the public in community-based policing." In this sense, the new management approach of the Nigeria police force has equipped with the required ability to operate an active community policing; involve in solving problems in the community; create avenue in building common interest and development values for everyone in the community (Kelling, 1988; Dandison, 2007).

\section{Community Partnership}

The policing process in Nigeria is required to empower neighbourhood citizens to engage in crime prevention. This is achieved through active cooperation between the police and members of the neighbourhood in attempt to gather and share intelligence information to solve crime related and disorder issues (Okeshola \& Mudiare (2013). This conformed to Ikuteyijo (2009) who maintained that police-community partnerships formed in support of community crime prevention efforts shall always provide a framework for engaging citizens to assist the law enforcement agent in gaining wide and easy access into valuable community information. While the Nigeria police force is expected to employ adequate police personnel, police-community teamwork spirit is emphasised to unravel the grip of boko haram terrorist group, Fulani herdsmen banditry, kidnappers and other criminals in Nigeria who are expected to vanish like smoke when the police-community partnership is active.

\section{Community Engagement}

According to Okiro (2007), community engagement is inseparable from policecommunity partnership. It is a major point of departure from the incidence-based traditional policing in Nigeria to engage neighbourhood stakeholders for effective control and management crime and disorder. By engaging the neighbourhood residents, the police will not just have easy and timely access to covert crime related information; but, the police are able to engage the neighbourhood teamwork spirit to keep peace, maintain security and sustain build mutual relationship and public trust. This view is conformed to Kelling (1988) that the ability of community members to produce dynamic neighbourhood watch network and protect them against predators are stimulated by police. This was also the position of Zhao (2003) who posited that the police need to pay much attention to how communities mobilise and develop trust for engaging in police-public teamwork policing.

\section{Organisational Transformation}

How would the community policing fit into the Nigeria police system that was cultured and familiar with the traditional policing model that has always alienated neighbourhood residents from police functions; is what this paper is concerned with. This supported Kelling (1988) that the police would radically alter its reactive traditional policing model to suit the requirement of people-oriented police system. Similarly, Goldstein (1990) argued that the philosophy of community policing is at survival risk, if the police failed to change its old orientation and still get on with the traditional ways alongside with the community policing. Therefore, the stance of this paper is well acknowledged in Brown (2009) that organisational transformation is a driver of community engagement, self-help, problem solving, change management, and police-community 
partnership in attempt to properly implement the ethos of community policing. Without reorientation, the issue of integrating community policing would be unrealistic in the Nigeria police force.

\section{Self-Help}

As Arase (2016) remarked, the idea of community policing as a shift from the precolonial traditional policing perspective has a lot of charming things to bear. Most importantly, it hugs on 'do-it-yourself' way of control and management of crime. What this implies is for the Nigeria police force to genuinely allow members of the neighbourhood to participate in keeping peace, securing and protecting their own areas. The paper aligned with Arase (2016) that community policing paves way for the neighbourhood dwellers to actively develop and implement ranges of self-help projects and activities that promote their shared interests and improve the quality of their living standard. It also identified with Abba (2014) that community policing is hinged on the belief that fellow citizens protect and serve themselves through ranges of self-initiated laudable programmes.

\section{Conclusion}

The paper assessed the relevance of community policing approach in Nigeria. As a theoretical model, community policing is focused on bringing the police and public together to engage and participate in policing in order to prevent crime and keep peace; maintain law and order; and guarantee safety and freedom to make life meaningful for everyone. It is contended that where the Nigeria police and residents of every community in Nigeria is encouraged to work together as a team, the chances of the alleged boko haram terrorist sect, Fulani herdsmen banditry, and other hoodlums to carry-out crime activities and escape undetected in any community are very constricted. With this in practice, the issue of threats arising from boko haram sect, farmers-herdsmen, ritualism, political assassin and thugs, kidnappers, or other banditries shall be surmounted and Nigeria will be a safer place for all.

The paper observed that community policing is yet to have positive effect on crime reduction and maintenance of peace in Nigeria. As the study noted, a feedback of the community policing integrated to the police system on 27th April 2004 showed an impressive outcome in the twelve selected pilot States (Dawodu, 2007; The Dawn Newspaper, 2011; Nwanguma, 2012; \& Ibrahim, 2017). But, it failed to be sustained due to reasons of policy summersault and inability to discard the traditional policing system in the country.

Based on the constant stream of insecurity in Nigeria, the Federal Government reintroduced community policing system in 2020 and its implementation commenced with recruitment and training of community policing constables. However, these set of police officers were trained by police instructors with traditional police orientations and deployed to their place of origins to perform their police duties under the supervision of their superiors who are still traditional policing practitioners. Of truth, the recruitment exercise seems to be useful in strengthening the police manpower problem. Also, it has helped to reduce the stream of unemployed youths who have stayed idle in Nigeria streets. So, there is no gainsaying the fact that the kind of community policing presently adopted in Nigeria 
was inappropriate and not good enough to achieve peace and maintain good order. Consequently, the level of crimes and criminalities has continued to grow worse daily in Nigeria while the unfriendly relationship between the police and members of the public continue to be deepened. This was manifested in the recent "\#EndSARS" protests in Nigeria, which has destroyed colossal lives and valuable properties (Okolie \& Ezirim, 2020). Also, Adeniji (2021:4) documented the worries of Professor Wole Soyinka over the daily killings and kidnappings of innocent people across Nigeria and allegedly told the Federal Government that "Youths should not serve as ritual offering on the altar of a failing state.” This is what Arase (2016:5) referred to as “a wake-up call” for the Nigeria police to embrace an active community engagement in policing Nigeria.

Therefore, the paper concluded that community policing model, which brings police and members of the neighbourhood together for teamwork would have positive effects on crime reduction; promoting peace and order; ensuring freedom; enhancing police-public friendly relations and trust; making Nigeria safer, comfortable and habitable place for everyone when it is properly maintained and implemented. The paper advised that any government or police effort to abate the stream of insecurity and venoms of disorder in Nigeria without sincerity and active police-community engagement would remain an act of building a castle on the air. This should not be misconstrued because; when most Nigerians believed that government is unfair; when most Nigerians lost trust on security agencies; when most Nigerians perceived the police as their worst enemies; when most Nigerians concealed criminal and crime; and when the philosophy that fosters the police-public teamwork for solving problems together in the community is blatantly ignored? Except all the aforementioned are well corrected, then, any government or police agenda to keep peace and enforce law to enhance a safer, habitable, and comfortable Nigeria will at best be a transitory daydream.

\section{References}

1. Abba, S. (2014). Forward in Force Order 464: Guidance for the Conduct of Beat and Patrol. Ikeja, Lagos: Police Printing Press

2. $\quad$ Abba, S. (2014). Forward in Force Order 468: Guidance for Conducting Tactical Operation Points Ikeja-Lagos: Police Printing Press

3. Adeola, P. B. (1987). “Anini being tied to drum with other criminals and shot by Nigerian Forces.” Paradise Daily News, Sunday, March 29

4. $\quad$ Adeniji, G., (2021). Students' killing: Swallow your vain pride and seek help, Soyinka tells FG. The Punch Newspaper, Sunday, April 25

5. Akinwotu, E, (2029). "Kidnapped 344 Released - Gov, The Guardian Newspaper, Thursday, December 17

6. Alemika E. O. (2005). Police Public Community Relations in Nigeria. Yaba-Lagos: Nwankwo Publishing Company

7. $\quad$ Alemika, E. O. (2012). Community Needs and Community Oriented Policing in Nigeria. Nsukka: Nwankwo Publishing Limited

8. Arase, S. E, (2016). IG Tasks Policemen on Professional Best Practices. The New Telegraph, Friday, April 15

9. Bello-Imam, I. B. (2010). 50 Years of the Nigerian Project: Challenges and Prospects. Ibadan: College Press and Publishers Limited

10. Brown, L.P. (2009) Community policing: A practical guide for police officials: Washington, D.C: Institute of Justice. 
11. Bureau of Justice Assistance (1994). Understanding Community Policing.:A Framework for Action. Washington DC: US Department of Justice

12. Chukwuma, I. (2003). Criminal Victimisation, Safety, and Policing in Nigeria. Lagos: Cleen Foundation

13. Dandison, N. O. (2007). Community Policing: Nigeria in Focus. Enugu: Syon Prints Ventures'

14. Dickson, O., (2007). Towards Alternative to the Police Traditional Arrangment in Nigeria. London: Old Bailey Press

15. Dawodu, C. A. (2007). The Nigeria Police and the Challenges of Democratic Consolidation. Lagos: Silmak Associates-Mekanand Publications

16. Farm House Dialogue (1994). Police and Society: Proceedings of Dialogue on Police and Society, held on November, 4-6, at Obasanjo Farms, Ota, Ogun State

17. FGN (1999). The Constitution of the Federal Republic of Nigeria. Lagos: Government Press

18. FGN (2015). Administration of Criminal Justice Act. Lagos: Government Press

19. Gordner, G. (2014). The Oxford Handbook of Police and Policing. Oxford: Oxford University Press

20. Gordner, G. (1996). Community Policing: Princiles and Elements. Kentucky: Eastern Kentucky University

21. Goldstein, H. (1977). Policing a Free Society. Cambridge: Ballinger Press

22. Goldstein, H. (1990). Problem Oriented Policing. New York: McGraw Hill

23. Ibrahim, I. (2017). Why Nigeria needs community policing - Ex-IGP Arase. Premium Times Newspaper, Saturday, December 2

24. Igbo, E. U, M. \& Anugwon, E. E. (2001). Socioloy: Basic Concepts and Issues. Nsukka: AP Executive Publishers

25. Ikuteyijo, L. \& Rotimi, K. (2010). The Police in a Federal State: The Nigerian Experience. Ibadan: College Press

26. Ikuteyijo, L. O. (2009). The Challenges of Community Policing in Nigeria. International Journal of Police Science and Management, Vol. 11, No. 2, 285-293

27. Kelling, G. I. (1988). Police and Community: The Quiet Revolution Perspectives on Policing. Washington DC: National Institute of Justice and Harvard University

28. Nwachukwu, O. N. (2011). Issues on Community Policing: The Role of Police Community Relations and Police Human Relationships in Community Policing The Nigerian Experience. Enugu: Cesmart Publishing Support Services.

29. Nwakaman, E. (2012). The Nigeria Police and the Sociology of Crime Control. Enugu: Smart Nigeria Limited.

30. IACP (2005). Post 9-11 Policing: The Crime Control - Homeland Security Paradigm: Taking Command of New Realities. US Department of Justice

31. Oikhala, G. I. (2019). Internal Security Architecture Management and Quest for State Police in Nigeria's Fourth Republic: A Critical Perspective. Review of Public Administration Management, Vol. 8 (15),39-49

32. Okeshola, F. B. \& Mudiare, P. E. U. (2013). Community Policing in Nigeria: Challenges and Prospects. American International Journal of Contemporary Research. Vol. 3 No.7, 134-138

33. Okiro, M. M. (2007) Forward in Community Policing in Nigeria. The Nigeria Police Force Operational Handbook. Ikeja-Lagos: Police Printing Press

34. Okolie, A. M. \& Ezirim, G. E, (2020). “\#ENDSARS” Protests and Mindless Killings, Looting and Arson Across: A Press Release by the Nigerian Political Science Association on 21st October, 2020. Nsukka-Enugu: University of Nigeria

35. Onovo, O. O. (2009). The Annual Report of the Nigeria Police Force. Ikeja-Lagos: Police Printing Press

36. Olokor, F. (2020). Borno killings: Life has lost its value under Buhari - Northern Elders Forum. Punch Newspaper Wednesday, December 2

37. Oluwole, J., (2020). How 10,000 newly recruited constables will be deployed -Police. Premium Times Wednesday,, September

38. Onovo, O. O. (2009). Forward in the Annual Report of the Nigeria Police Force. Ikeja- The Lagos: Police Printing Press

39. Ordu, G. E. \& Nnam, M. U. (2017). Community Policing in Nigeria: A Critical Analysis of Current Development. International Journal Criminal Justice Sciences, Vol 12, Issue 1, 83-97 
40. Shaw, M. (2002). Crime and Policing in Post-Apartheid South Africa: Transforming Under Fire. Indian: Indian University Press

41. Shaw, M. (2000). Insecurity in Developing Countries Versus Community and Problem Oriented Policing. New Jersey, Upper Saddle River: Prentice Hall

42. Siegel, L. J. (2008). Criminology: The Core (3rd ed .) Belmont , California: Thomas Higher Education

43. Soni, D. (2019). Nigeria, 7 Others Nations home to World's Hungriest - UN, Abuja: Vanguard Newspaper, Thursday, April 4

44. Sykes, G. M. (1978). Criminology. New York: Harcourt Brace Jovanovich

45. Tobi, A. A. \& Oikhala, G. I. (2018). Police and Election Administration in Nigeria. International Journal of Public Administration, Finance, and Law, Issue No.14, 85-94

46. Toromade, S. (2018). Atiku says Boko Haram Terrorists started as Political Thugs. The Guardian Newspaper, Thursday, November 15

47. The Dawn Newspaper (2011). Community Policing and National Security: Community Policing in Nigeria. Thursday January, 27

48. The Nigeria Police Force (2011).Annual Report of the Nigeria Police Force. Ikeja-Lagos: Police Printing Press

49. The Nigeria Police Force (2014). Force Order 464: Guidance for the Conduct of Beat and Patrol. Ikeja-Lagos: Police Printing Press

50. The Nigeria Police Force (2014). Force Order 468: Guidance for Conducting Tactical Operation Points. Ikeja-Lagos: Police Printing Press

51. The Criminal Code Act, Law of the Federation of Nigeria 2004 as Amended

52. The Penal Act, Laws of the Federation of Nigeria 1960

53. Umeban, E. E. (2008). Rural Development and Management. Lagos: National Open University

Press

54. Wilson, J. Q. \& Kelling G. L. (1982). 'Broken Windows.' The Atlantic Monthly March Issue, 29-

38

55. Yakubu, D. (2019). FG committed to Community Policing - Osinbajo. Vanguard Newspaper, Tuesday, October 15

56. Zhao, J (2003), Community Policing: Did It Change the Basic Functions of Policing in the 1990s? Washington, DC: Police Executive Research Forum

57. Zimbardo, P. G. (169). The Human Choice: Individuation, Reason, and Order Versus Deindividuation, Impulse, and Chaos. In Nebraska Symposium on Motivation, Nebraska: Nebraska University Press. Creative Commons Attribution - Non Commercial - No Derivatives 4.0 International License. 